\section{Food safety objectives, criteria, ranking and hierarchization}

Gaetano Liuzzo, ${ }^{1}$ Stefano Bentley, ${ }^{2}$ Federica Giacometti, ${ }^{3}$ Silvia Piva, ${ }^{3}$ Andrea Serraino ${ }^{3}$

${ }^{1}$ Modena Local Health Unit, Carpi; ${ }^{2}$ Department of Veterinary Sciences, University of Parma; ${ }^{3}$ Department of Veterinary Medical Sciences, University of Bologna, Ozzano dell'Emilia, Italy

\begin{abstract}
The paper describes the terminology of risk in the view of food safety objectives, criteria, ranking and hierarchization: the terms Performance Criterion, Process Criteria, Product Criterion, Microbiological Criteria, Food Safety Objective, Performance standard, Food safety policy objectives, Risk Assessment Policies, Weighing, Precaution, Prevention, Precautionary principle, Prevention principle, Principle of separation between risk assessment and management, Rank, Ranking, Categorization, Ranking, Priorization, ALARA (As Low Reasonably Achievable), ALOP (Appropriate level of protection), Risk Management, Risk management in the public function are reported and discussed.
\end{abstract}

\section{English version}

\section{Performance criterion (PC)}

The effect in frequency and/or concentration of a hazard in a food that must be achieved by the application of one or more control measures to provide or contribute to a PO or an FSO. It can be expressed as an expected reduction or an acceptable increase in the concentration of a hazard during the application of a control measure. A typical example of $\mathrm{CP}$ is represented by the expected 12 decimals reduction of $C$. botulinum spores following the thermal treatment of canned products (FAO/WHO, 2002; CAC, 2015; CAC, 2016).

\section{Process criteria}

The parameters (eg $t / t^{\circ}$ ratio) of a control measure that, if properly applied, can meet the Performance Criterion alone or along with other control measures. For example, in order to meet the CP of 12 decimals' reduction of $C$. botulinum spores, a temperature of $121^{\circ} \mathrm{C}$ for at least 2.4' is required (Cerf, 2004; ALINORM, 2013).

\section{Product criterion}

Specifies a chemical or physical food pattern (e.g. $\mathrm{pH}$, water activity) that, if correctly applied as a control measure, meets the Performance Criterion alone or in combination with other control measures. For example, the acidity and the $\mathrm{pH}$ required in order to comply with the Performance Criterion if these parameters are able to reduce the growth rate of a hazard in the food. A pH of 4.6 for acid preservatives prevents the development of $C$. botulinum (ALINORM, 2013).

\section{Microbiological criteria}

A microbiological criterion for food defines the acceptability of a product or a food lot based on the absence or presence or number of microorganisms including parasites, and/or quantity of their toxins/metabolites, per unit(s) of mass, volume, area or lot. A microbiological criterion consists of (CAC, 1997):

i. a statement of the microorganisms and/or their toxins/metabolites of concern;

ii. the analytical methods for their detection and/or quantification;

iii. a sampling plan;

iv. microbiological limits;

v. the number of analytical units that should conform to these limits;

vi. the food to which the criterion applies;

vii. the point(s) in the food chain where the criterion applies;

viii. any actions to be taken when the criterion is not met.

\section{Food safety objective (FSO)}

The maximum frequency and/or concentration of a hazard in a food at the time of consumption that provides or contributes to the appropriate level of protection (ALOP). FSO is established through the dose/effect ratio, i.e. the relationship between the risk to public health and the concentration of food hazard at the time of consumption; an example of FSO is the Listeria monocytogenes threshold level of $100 \mathrm{CFU} / \mathrm{g}$ in ready-to-eat foods. Since they are set at the time of consumption, they will have to be converted to performance objectives, performance criteria, process criteria or microbiological criteria (FAO/WHO, 2002; CAC, 2016).

\section{Performance standard}

According to Van Schothorst (2002), a standard performance is the level of danger that can be obtained at a specific point in the food chain. The use of the term "standard" does not imply that the specified level of danger is a mandatory regulatory requirement. Microbiological specifications can be useful
Correspondence: Andrea Serraino, Department of Veterinary Medical Sciences University of Bologna, via Tolara di Sopra 50, 40064 Ozzano dell'Emilia (BO), Italy.

Tel.: +39.051.2097323.

E-mail: andrea.serraino@unibo.it

Key words: food safety objectives, criteria, ranking and hierarchization.

Contributions: The authors contributed equally

Conflict of interest: The authors declare no potential conflict of interest.

Funding: none.

Received for publication: 2 March 2018.

Accepted for publication: 13 March 2018

This work is licensed under a Creative Commons Attribution-NonCommercial 4.0 International License (CC BY-NC 4.0).

(C) Copyright G. Liuzzo et al., 2018

Licensee PAGEPress, Italy

Italian Journal of Food Safety 2018; 7:7395

doi:10.4081/ijfs.2018.7395

for defining the acceptability of raw materials, ingredients, products, and in some circumstance's product lots. According to the Institute of Medicine/National Research Council, a PS represents the degree to which a step or combination of steps in the production, processing, distribution, and/ or preparation of a food must operate to achieve the required level of control over a hazard. This parameter is more focused than the performance criterion and, in certain instances, can be mandatory if incorporated into a law, regulation, or ordinance. Examples of PS can be: PS of Salmonella, Zero Tolerance PS for E.coli O157:H7 in raw minced meat, PS for Lethality and Stabilization for Cooked Products, all issued by USDA/FSIS (I.F.T 2004).

\section{Food safety policy objectives}

From a strictly economic point of view, the main objectives of a food safety policy are: reducing the costs associated with the damage caused by the use of a product and the community as a whole, yet protecting free choice; helping consumer to know the products' features, thus reducing the chance of marketing-induced mystification; standardization of production processes and/or product characteristics in order to discover, limit, and pursue the behaviors and (mis)information that may cause harm to the consumer. It is clear that food safety policies should be designed and implemented in relation to the health risk assessment in consumers (Caiati, 1999). 


\section{Risk assessment policies}

Documented guidelines on the choice of options and associated judgements for their application at appropriate decision points in the risk assessment so that the scientific integrity of the process is maintained (WHO/FAO, 2007; CAC, 2016).

\section{Weighing}

The action of giving different importance to criteria or fields thereof (ANSES, 2010).

\section{Precaution}

Refers to unforeseeable events that cannot be represented, in a situation of uncertainty about the likelihood that damage will occur (Marini, 2004).

\section{Prevention}

It involves clear and impending risks, in the presence of a pre-existing deterioration (Marini, 2004).

\section{Precautionary principle}

In specific circumstances where, following an assessment of available information, the possibility of adverse health effects is identified but scientific uncertainty persists, provisional risk management measures necessary to ensure the high level of health protection chosen in the Community may be adopted, pending further scientific information for a more comprehensive risk assessment.

Measures adopted on the basis of paragraph 1 shall be proportionate and no more restrictive of trade than is required to achieve the high level of health protection chosen in the Community, with regard to technical and economic feasibility and other factors regarded as legitimate in the matter under consideration. The measures shall be reviewed within a reasonable period of time, depending on the nature of the risk to life or health identified and the type of scientific information needed to clarify the scientific uncertainty and to conduct a more comprehensive risk assessment (European Commission, 2002).

\section{Prevention principle}

Principle according to which, in the presence of real risks, (whose dangerousness of induced effects is already established although the likelihood of occurrence may be otherwise assessable) appropriate measures to remove/contain the risk can be enforced (Bioethics national committee, 2004).

\section{Principle of separation between risk assessment and management}

Principle adopted by Regulation (European Commission) 178/2002 in implementation of the guidelines set out in the White Paper on Food Safety and tracing the Authority's sphere of competence in risk analysis. European food law introduces a partition of tasks between controls, risk assessment and risk management, respectively entrusted to national official systems, to the Authority and to the Commission (Cassese, 2002). The functional separation between risk assessment and management is first established in the "General principles of food safety risk management" (WHO/FAO, 1997) and resumed by the European legislator, thus avoiding entrusting Authority with a regulatory power that would only require a modification of the EU treaty. This laid the ground stone for independence of scientific functions (Costato et al., 2003)

\section{Rank}

Position in an orderly set (ANSES, 2010).

\section{Ranking (risk)}

Also known as Comparative Risk Assessment, it allows to sort and classify compared risks (Shaw, 2003). This concept is treated as distinct from a risk prioritization, which may involve additional non-scientific information and considerations, such as political and social criteria. In most cases risk ranking in food safety could be defined as the analysis and ranking of foodborne pathogens based upon the combined probability of food contamination, consumer exposure and the public health impact of certain foodborne hazards (EFSA, 2012).

Risk Ranking is used within the Risk Management, aiming at of involving the public, identifying the biggest threats and classifying them, prioritizing and developing strategic actions/plans to reduce the risks. The model proposed by the New Zealand authorities envisages the development of a Risk Ranking through the implementation of 6 phases: problem definition, risk analysis, risk ranking, ranking of potential risk reduction measures and publication of the list with the identified priorities. There are several possible approaches for conducting a risk ranking and can be traced back to two large groups: those based on "top-down" surveillance and those based on "bottom-up" prediction (Newsome et al., 2009). The "top-down" approach to microbiological hazards attempts to infer the level of risk due to those foods, to those hazards or their combination based on information collected through various systems such as: disease reports, outbreak databases, observations such as the prevalence of pathogens in various types of food/products. These sources of information are useful for an overall classification of pathogens, but it is difficult to trace a quan- titative link between the data obtained and specific foods. An example of such approach is the Foodborne Illness Risk Ranking Model, developed by the Food Safety Research Consortium (Batz et al., 2004). This method integrates surveillance data on foodborne diseases, pathogen-food combination, clinical symptoms, complications and outcomes of the disease, economic impact, and social status assessments to make a judgment on the relevance of a potential public health hazard. This is possible and true for microbiological hazards, but with regard to chemical hazards, there is no systematic ability to observe the effects of exposure to chemical hazards associated with food within a population. The reasons should be found especially in the high number of potential symptoms, long latency between exposure and possible clinical evidence. With the bottom-up approach, on the other hand, reference is made to predictive models that can estimate the destiny of microbial or chemical agents in food products and their virulence or toxicity (EFSA, 2012; Batz et al., 2004; Newsome, 2009; Shaw, 2003).

\section{Categorization}

Hierarchization process according to which the diseases are grouped into multiple categories (ANSES, 2010).

\section{Ranking}

Hierarchization process by which the diseases are classified in a given order (ANSES, 2010).

\section{Priorization}

Organization of a set in a series in which each element is greater than the following for at least one N.B character: each element can be unique (ranking by rank) or multiple (categorization) (ANSES, 2010).

\section{ALARA (As Low Reasonably Achievable)}

Risk management measure that forces to take any possible action to keep the concentration of a compound in a food as low as possible since, as a matter of fact, it is often impossible to meet the tolerable daily dose

\section{Appropriate level of protection (ALOP)}

The SPS Agreement defines the appropriate level of sanitary or phytosanitary protection as the level of protection deemed appropriate by the Member establishing a sanitary or phytosanitary measure to protect human, animal or plant life or health within its territory (WTO, 1994). This concept is also referred to as the acceptable level of risk. The ALOP can be expressed implicitly or explicitly; in most cases implied LAP is 
expressed in terms of general public health objectives or law requirements ("reasonable certainty of the absence of harmful effects"). Since the ALOP is a mere statement of intent, it is not a control instrument for the food industry or health bodies. This criterion is needed to be converted into a controllable and above all measurable "something", so the concept of Food Safety Objective (OSA/FSO) (FAO/WHO, 2002) has been developed (WTO, 1994; FAO/OMS, 2002).

\section{Risk management}

The process, distinct from risk assessment, of weighing policy alternatives, in consultation with all interested parties, considering risk assessment and other factors relevant for the health protection of consumers and for the promotion of fair-trade practices, and, if needed, selecting appropriate prevention and control options (European Commission, 2002).

Risk management should follow a structured approach including preliminary risk management activities, evaluation of risk management options, monitoring and review of the decision taken (FAO/OMS, 2002).

\section{Risk management in the public function}

Risk management is the systematic approach that involves choosing the best course of action in a context of uncertainty, circumscribing and understanding risk issues, intervening at these levels and communicating these issues (SCT, 2001).

\section{Italian Version}

\section{Criterio di performance - $\mathrm{CP}$}

Il Criterio di Performance è l'effetto ricercato sulla frequenza e/o concentrazione di uno o più pericoli microbiologici presenti in un alimento in seguito all'applicazione di una o più misure di controllo, nell'intento di realizzare un OP o un OSA o di contribuire alla loro realizzazione. Può essere espresso come una riduzione attesa od un aumento accettabile della concentrazione di un pericolo durante l'applicazione di una misura di controllo. Tipico esempio di CP è rappresentato dalle 12 riduzioni decimali di spore di C. botulinum attese a seguito del trattamento termico dei prodotti in scatola (FAO/OMS, 2002).

\section{Criteri di processo}

I parametri (es. rapporto $\mathrm{t}^{\prime} / \mathrm{t}^{\circ}$ ) di una misura di controllo che, se correttamente applicata permette di soddisfare il Criterio di Performance, solo od insieme ad altre misure di controllo. Per soddisfare ad esem- pio il CP di 12 riduzioni decimali di spore di C. botulinum, sarà necessario applicare una temperatura di $121^{\circ} \mathrm{C}$ per almeno 2,4' (Cerf, 2004, ALINORM 2013).

\section{Criteri di prodotto}

La caratteristica fisica e/o chimica di un prodotto che correttamente applicata come misura di controllo, risponde al Criterio di performance solo od in combinazione con altre misure di controllo. Per es. l'acidità ed il $\mathrm{pH}$ richieste al fine di rispettare il Criterio di Performance qualora questi parametri siano in grado di ridurre il tasso di crescita di un pericolo nell'alimento. Un $\mathrm{pH} £ 4,6$ per le conserve acide impedisce lo sviluppo di C. botulinum (ALINORM, 2013).

\section{Criteri microbiologici - CM}

Un criterio che definisce i termini di accettabilità di un prodotto, di una partita di prodotti alimentari o di un processo, in base all'assenza, alla presenza, o al numero di microrganismi e/o in base alla quantità delle relative tossine/metabolici, per unità di massa, volume, area o partita (CAC, 1997).

Deve essere composto dei seguenti elementi: indicazione del microrganismo, tossina o metabolica indesiderato, metodo analitico, piano di campionamento, limite microbiologico, numero di unità campionarie che devono risultare conformi al limite indicato, tipo di alimento a cui si applicano, punti della filiera in cui si applicano e azioni da intraprendere in caso di mancato soddisfacimento (CAC, 1997).

\section{Obiettivo di Sicurezza Alimentare (degli alimenti) - OSA}

L'Obiettivo di Sicurezza Alimentare è la frequenza e/o concentrazione massima di un pericolo presente in un alimento al momento del suo consumo e che assicura il Livello Appropriato di Protezione della salute (LAP). L'OSA si stabilisce attraverso il rapporto dose/effetto, cioè la relazione tra il rischio per la salute pubblica e la concentrazione del pericolo al momento del consumo dell'alimento. Un OSA è il livello di $L$. monocytogenes di $100 \mathrm{UFC} / \mathrm{g}$ nei prodotti pronti al consumo. Raramente però gli OSA sono verificabili, in quanto sono fissati al momento del consumo, si dovranno convertire in obiettivi di performance, criteri di performance, criteri di processo o criteri microbiologici (FAO/OMS, 2002).

\section{Performance standard}

Secondo Van Schothorst (2002), il performance standard è il livello di pericolo che può essere ottenuto in un punto specifico della catena alimentare. L'uso del termine "standard" non implica che il livello specificato di pericolo sia un requisito normativo obbligatorio.
Criterio (specifica) microbiologico con cui si può definire l'accettabilità di una materia prima, un ingrediente, un prodotto ed in alcune circostanze un lotto di produzione. Per 1'Institute of Medicine/National Research Council, il PS è il livello al quale uno step o la combinazione di più step nel corso della produzione, processo, distribuzione e/o preparazione di un alimento deve operare per raggiungere il livello richiesto di controllo su un pericolo. Questo parametro è più mirato rispetto ai Criteri di performance e, in certi casi, può essere obbligatorio qualora fosse inserito in leggi, regolamenti o ordinamenti. Alcuni esempi di performance Standard sono: PS of Salmonella, Zero Tolerance PS per E.coli O157:H7 carne macinata cruda, PS per Lethality and Stabilization for Cooked Products, tutti espressione dell'FSIS/USDA americani (I.F.T. 2004).

\section{Obiettivi della politica della sicurez-} za alimentare (degli alimenti)

In un'accezione marcatamente economicistica, sono obiettivi di una politica della sicurezza degli alimenti: minimizzare i costi connessi a danni arrecati all'utilizzazione di un prodotto e alla collettività nel suo complesso, pur nella tutela delle libere scelte dei consumatori; fornire al consumatore la conoscenza del prodotto, la quale può contribuire a ridurre la possibilità di mistificazione messa in atto dai produttori attraverso strumenti di marketing; standardizzazione dei processi produttivi e/o delle caratteristiche del prodotto al fine di scoprire, limitare e perseguire i comportamenti e le informazioni che possono in qualsiasi modo arrecare danno al consumatore. E' evidente che le politiche che riguardano la sicurezza degli alimenti devono essere concepite e poste concretamente in essere in relazione alla valutazione dei rischi sulla salute dei consumatori (Caiati, 1999)

\section{Politiche di valutazione del rischio}

Le linee guida documentate sulla scelta delle opzioni e dettami connessi alla loro applicazione nei punti di decisione appropriati nel corso della valutazione dei rischi al fine di mantenere l'integrità scientifica del processo (WHO/FAO, 2007; CAC, 2016).

\section{Ponderazione}

Azione con cui si accorda un peso differente a dei criteri o a dei domini (campi) di criteri (ANSES, 2010).

\section{Precauzione}

Concerne eventi non anticipabili né rappresentabili, in una situazione di incertezza circa la possibilità stessa che un danno si verifichi (Marini, 2004). 


\section{Prevenzione}

Concerne i rischi certi e imminenti, in presenza di una situazione di degrado preesistente (Marini, 2004).

\section{Principio di precauzione}

Qualora, in circostanze specifiche a seguito di una valutazione delle informazioni disponibili venga individuata la possibilità di effetti dannosi per la salute ma permanga una situazione d'incertezza sul piano scientifico, possono essere adottate le misure provvisorie di gestione del rischio necessarie per garantire il livello elevato di tutela della salute che la Comunità persegue, in attesa di ulteriori informazioni scientifiche per una valutazione più esauriente del rischio.

Le misure adottate sulla base del paragrafo 1 sono proporzionate e prevedono le sole restrizioni necessarie al commercio che siano necessarie per raggiungere l'elevato livello di tutela della salute perseguito nella Comunità, tenendo conto della realizzabilità tecnica ed economica e di altri aspetti, se pertinenti. Tali misure sono riesaminate entro un periodo di tempo ragionevole a seconda della natura del rischio per la vita o per la salute individuato e del tipo di informazioni scientifiche necessarie per risolvere la situazione di incertezza scientifica e per realizzare una valutazione del rischio più esauriente (European Commission, 2002)

\section{Principio di prevenzione}

Principio secondo il quale, in presenza di rischi reali, la cui pericolosità degli effetti indotti sia già stabilita anche se possa essere diversamente valutabile la probabilità che l'evento rischioso si produca, si opera con misure adeguate per allontanare/contenere il rischio (Comitato Nazionale di Bioetica, 2004).

\section{Principio di separazione tra valutazione e gestione del rischio}

Principio adottato dal Reg. (European Commission) 178/2002 in attuazione delle linee programmatiche disposte dal Libro bianco sulla sicurezza alimentare e relative alla delimitazione della sfera di competenza dell'Autorità nell'ambito della analisi del rischio. La disciplina alimentare europea, introduce una divisione del lavoro, distinguendo controlli, valutazione del rischio, gestione del rischio, attribuiti rispettivamente ai sistemi ufficiali nazionali, all'Autorità e alla Commissione (Cassese, 2002). La separazione funzionale tra valutazione e gestione del rischio viene affermata dapprima in campo internazionale nei "Principi generali della gestione dei rischi nel campo della salubrità degli alimenti" (OMS/FAO, 1997) e ripresa dal legislatore europeo che così facendo ha evitato di conferire all'Autorità un potere normativo che avrebbe richiesto se non altro una modifica del Trattato istitutivo dell'U.E. In questo modo si sono create le premesse per un espletamento delle funzioni scientifiche il più indipendente possibile (Costato et al., 2003).

\section{Rank}

Posizione in un insieme ordinato (ANSES, 2010).

\section{Ranking (risk)}

Si definisce Risk ranking o Valutazione Comparativa del Rischio, il processo di comparazione dei rischi con il loro ordinamento e classificazione (Shaw, 2003). Il concetto deve essere distinto da quello di Priorizzazione del Rischio in cui nella comparazione e classificazione vengono valutate anche informazioni "non scientifiche" di tipo politico e/o sociale.

Secondo una rassegna dell'EFSA (2012), nella maggior parte dei casi il Risk Ranking nell'ambito della sicurezza degli alimenti può essere definito come l'analisi e la classificazione degli agenti patogeni trasmissibili con gli alimenti sulla base della combinazione fra la probabilità di contaminazione dell'alimenti, l'esposizione dell'agente patogeno al consumatore attraverso il consumo dell'alimento contaminato e l'impatto dello stesso sulla salute pubblica).

Il Risk Ranking si inserisce a pieno titolo nella fase di Gestione del Rischio con l'obiettivo di coinvolgere il pubblico, identificare le minacce più grandi e classificarle, stabilire delle priorità e sviluppare delle azioni/piani strategici per ridurre i rischi. Il modello proposto dalle autorità della Nuova Zelanda prevedono lo sviluppo di un Risk Ranking attraverso l'implementazione di 6 fasi: la definizione del problema, l'analisi del rischio, il risk ranking, il ranking delle misure di riduzione potenziale del rischio e la pubblicazione della lista con le priorità che sono state identificate. Sono diversi gli approcci possibili per la conduzione di un risk ranking e si possono ricondurre a due grandi gruppi: quelli basati sulla sorveglianza "top-down" e quelli basati sulla predizione "bottom-up" (Newsome et al., 2009). L'approccio "top-down" rispetto ai pericoli microbiologici, cerca di desumere il livello di rischio dovuto a quegli alimenti, a quei pericoli o alla loro combinazione basandosi su informazioni raccolte attraverso vari sistemi come: reports di malattie, banche dati di focolai, osservazioni quali la prevalenza di patogeni in vari tipi di alimentiprodotti. Queste sorgenti d'informazione sono utili per una complessiva classificazione, è difficile però collegare "quantitativamente" i dati così ottenuti ad alimenti in particolare. Un esempio di questo tipo di approccio è il F.I.R.R.M (Foodborne Illness Risk Ranking Model) messo a punto dal Food Safety Research Consortium (Batz et a1., 2004). È questo un metodo che integra $i$ dati di sorveglianza sulle malattie trasmesse attraverso gli alimenti, la combinazione patogeno-alimento, i sintomi clinici, le complicazioni e gli esiti della malattia, l'impatto economico e le valutazioni di ordine sociale per arrivare ad un giudizio sulla rilevanza di un pericolo potenziale per la salute pubblica. Se tutto ciò è possibile e vero per i pericoli microbiologici, diverso è il caso riguardo ai pericoli chimici, in questi casi infatti non esiste la sistematica capacità di osservare gli effetti di una esposizione ad alimenti associati ai pericoli chimici nella popolazione. Le ragioni sono da ricercare soprattutto nel numero elevato delle potenziali cause sintomatologiche, la lunga latenza fra esposizione e manifestazioni cliniche eventuali. Con l'approccio "bottom-up" si fa riferimento invece a modelli predittivi in grado di valutare il destino degli agenti microbici o chimici nei prodotti alimentari e la loro virulenza e tossicità.

\section{Categorizzazione}

Processo di gerarchizzazione in base al quale le malattie sono raggruppate in più categorie (ANSES, 2010).

\section{Classifica (graduatoria)}

Processo di gerarchizzazione per il quale le malattie sono classificate in un ordine dato (ANSES, 2010).

\section{Gerarchizzazione}

Organizzazione di un insieme in una serie nella quale ciascun elemento è superiore al seguente per almeno un carattere N.B.: ciascun elemento può essere unico (classifica per rang) o multiplo (categorizzazione) (ANSES, 2010).

\section{ALARA (As Low Reasonably Achievable)}

Misura di gestione (del rischio) secondo la quale è necessario fare tutto quello che è possibile per mantenere la concentrazione di un composto in un alimento la più bassa possibile; nella realtà è spesso impossibile rispettare la dose giornaliera tollerabile.

\section{Livello Appropriato di Protezione - LAP}

Il livello di protezione giudicato appropriato da parte del paese che stabilisce una o più misure sanitarie volte a proteggere la salute del consumatore all'interno del proprio territorio. Il LAP può essere espresso in modo implicito od esplicito, nella maggior parte dei casi il LAP implicito si esprime in termini di obiettivi generali di sanità pubblica o di esigenze normative ("certezza ragio- 
nevole dell'assenza di effetti nocivi"). Il LAP rappresenta una dichiarazione d'intenti è come tale non può essere considerato uno strumento di controllo né per l'industria alimentare né per le autorità sanitarie. Questo criterio necessita al fine della sua soddisfazione di essere convertito in un "qualcosa" di controllabile, ma soprattutto misurabile. A questo scopo si introduce quindi il concetto di Obiettivo di Sicurezza Alimentare (OSA/FSO) (FAO/OMS, 2002).

\section{Gestione del rischio}

Definizione legale: «gestione del rischio», processo, distinto dalla valutazione del rischio, consistente nell'esaminare alternative d'intervento consultando le parti interessate, tenendo conto della valutazione del rischio e di altri fattori pertinenti e, se necessario, compiendo adeguate scelte di prevenzione e di controllo (EC, 2002).

Processo che consiste nel mettere in bilancio le differenti politiche possibili tenuto conto dei risultati della valutazione dei rischi e, al bisogno, nella scelta e realizzazione di misure di controllo appropriate, ivi comprese le misure di regolamentazione (CAC, 2015) “...processo, distinto dalla valutazione del rischio, consistente nell'esaminare alternative d'intervento consultando le parti interessate, tenendo conto della valutazione del rischio e di altri fattori pertinenti e, se necessario, compiendo adeguate scelte di prevenzione e di controllo" (EC, 2002).

Schematicamente tale processo si compone delle seguenti fasi: attività preliminari, valutazione delle opzioni in materia di gestione del rischio, applicazione della decisione, controllo ed analisi (FAO/OMS, 2002).

\section{Gestione del rischio nella funzione pubblica}

La gestione del rischio è l'approccio sistematico che consiste nello scegliere la migliore linea di condotta, in un contesto d'incertezza, circoscrivendo e comprendendo le questioni attinenti al rischio, intervenendo a questi livelli e comunicando queste questioni (SCT, 2001)

\section{References}

ALINORM, 2013. 05/28/13, Annexe III. ANSES, 2010. Méthodologie de hiérarchisation des maladies animales; application aux agents pathogènes exotiques,
Rapport d'expertise collective Groupe de Travail «Méthodologie de hiérarchisation des maladies animales » Comité d'experts spécialisés « Santé animale », Paris, November 2010,

Batz MB, Hoffmann SA, Krupnick AJ, Morris JG, Sherman DM, Taylor MR, Tick JS, 2004. Identifying the most significant microbiological foodborne hazards to public health: a new risk ranking model. Food Safety Research Consortium, Discussion paper series, number 1.

CAC, 1997. CAC/GL 21 Principles for the establishment and application Of microbiological criteria for foods

CAC, 2007. CAC/GL 63-2007. Priciples and guidelines for the conduct of microbiological risk management (MRM).

CAC, 2015. Procedural Manual, Twentythird edition. Joint FAO/WHO Food Standards Programme, Rome, 2015.

CAC, 2016. Procedural Manual, Twentyfifth edition, Rome.

Caiati G, 1999. Economia e politica della sicurezza alimentare, Rivista di Economia Agraria, 4:565-600.

Cassese S, 2002. Per un'autorità nazionale della sicurezza alimentare, Il Sole 24Ore Ed., Milano, 15

Cerf O, 2004. Third International Workshop Microbial Risk Assessment and Mitigation, 21-25 giugno 2004, Pamplona, Spain.

Comitato Nazionale di Bioetica-Presidenza del Consiglio dei Ministri, Il principio di Precauzione: profili bioetica, filosofici, giuridici, 18 giugno 2004.

Costato L, Bolognini S, 2003. "Note introduttive" in "La sicurezza alimentare nell'Unione europea", Le Nuove Leggi Civili Commentate, XXVI, 1-2: 114130.

EFSA Panel on Biological Hazards (BIOHAZ), 2012. Scientific Opinion on the development of a risk ranking framework on biological hazards. EFSA Journal 10:2724.

European Commission, 2002. Regulation of the European Parliament and of the Council of 28 January 2002 laying down the general principles and requirements of food law, establishing the European Food Safety Authority and laying down procedures in matters of food safety, 178/2002/CE. In: Official Journal, L 31/1, 01/02/2002.
FAO/OMS, 2002. Principe et lignes directrices en vue de l'incorporation de l'évaluation du risque microbiologique dans l'élaboration de norme, de lignes directrices et de textes connexes en matiére de sécurité sanitarie des aliments.

FAO/OMS, 2002. Principes et lignes directrices en vue de l'incorporation de l'évaluation du risque microbiologique dans l'élaboration de normes, de lignes directrices et de textes connexes en matière de sécurité sanitarie des aliments", Rapport, Kiel, Allemagne, 1822 mars 2002.

FAO/OMS, 1997. Risk management and food safety, FAO Food and Nutrition paper, 65, Roma.

I.F.T (Institute of Food Technologists), 2004. Managing Food Safety: use of performance standards and other criteria in food inspection systems.

Marini L, 2004. Il principio di precauzione nel diritto internazionale e comunitario, CEDAM Ed., Padova.

Newsome R, Tran N, Paoli GM, Jaykus LA, Tompkin B, Miliotis M, Ruthman T, Hartnett E, Busta FF, Petersen B, Shank F, McEntire J, Hotchkiss J, Wagner M, Schaffner DW, 2009. Development of a risk-ranking framework to evaluate potential high-threat microrganisms, toxins, and chemicals in food. J Food Sci 74:R39-45

Secrétariat du Conseil du Trésor, 2001. Pratiques exemplaires de gestion des risques. Avalable from: www.tbssct.gc.ca.

Shaw I, 2003. Ranking Food Safety Risks. A discussion document. Institute of Environmental Science \& research Limited, New Zealand.

Van Schothorst M, 2002. Implementing the results of an MRA: pathogen risk management. In M. Brown \& M. Stringer (Eds.). Microbiological risk assessment in food processing. Cambridge, England: Woodhead Publishing Ltd.

WHO/FAO, 2007. Working Principles for Risk Analysis for Food Safety for Application by Governments, First edition.

WTO. The WTO agreement on the application of sanitary and phytosanitary measures, Annex A, Definitions. Available at https://www.wto.org/english/ tratop_e/sps_e/spsagr_e.htm. 